\title{
Wound Healing Effectivity of the Ethanolic Extracts of Ageratum conyzoides L. Leaf (White and Purple Flower Type) and Centella asiatica and Astaxanthin Combination Gel Preparation in Animal Model
}

\author{
Ageratum conyzoides L. Yaprağı (Beyaz ve Mor Çiçekli Tür) ve Centella \\ asiatica Etanol ile Hazırlanmış Ekstreleri Astaksantin Kombinasyonunu \\ İçeren Hazırlanmış Jelin Hayvan Modelinde Yara İyileştirici Etkisi
}

\author{
(D) Yedy Purwandi SUKMAWAN ${ }^{*}$, (D) Ilham ALIFIAR , (D) Lusi NURDIANTI², (D) Widar Rahayu NINGSIH ${ }^{1}$ \\ ${ }^{1}$ Bakti Tunas Husada Health Science College, Department of Pharmacology and Clinical Pharmacy, Tasikmalaya, Indonesia \\ 2Bakti Tunas Husada Health Science College, Department of Pharmaceuthics, Tasikmalaya, Indonesia
}

\begin{abstract}
Objectives: The study's objective was to determine the wound healing activity of the combination of ethanolic extracts of Ageratum conyzoides $\mathrm{L}$. leaf (white and purple), Centella asiatica, and astaxanthin gel preparation.

Materials and Methods: For in-gel preparation, three different formulas of gelling agents, namely carbopol 934 (1\%), hydroxypropyl methylcellulose (HPMC) (9\%), and natirum-carboxymethylcellulose ( $\mathrm{Na}-\mathrm{CMC})(4 \%)$, were employed. Then, the organoleptic, pH, spreadability, and viscosity of the formulas were evaluated. To determine wound healing activity, six treatments, including negative control (placebo), positive control (bioplacenton), BP5 (A. conyzoides L. leaf ethanolic extract of white flower type 5\%, C. asiatica L. Urb leaf ethanolic extract $2.5 \%$, astaxanthin $0.05 \%$ ), BU5 ( $A$. conyzoides $\mathrm{L}$. leaf ethanolic extract of purple flower type $5 \%, C$. asiatica $\mathrm{L}$. Urb leaf ethanolic extract $2.5 \%$, astaxanthin $0.05 \%), B U 10(A$. conyzoides $\mathrm{L}$. leaf ethanolic extract of purple flower type $10 \%, C$. asiatica L. Urb leaf ethanolic extract $5 \%$, and astaxanthin $0.1 \%$ ), and BP10 (A. conyzoides L. leaf ethanolic extract of white flower type $10 \%$, C. asiatica L. Urb leaf ethanolic extract $5 \%$, and astaxanthin $0.1 \%$ ) were evaluated. All treatments were applied to an incision wound $(1.5 \mathrm{~cm})$. Measurement of the wound length was conducted daily for 14 days.

Results: The results showed that the carbopol 934 (1\%) gelling agent formula was better than HPMC and Na-CMC. Meanwhile, the percentages of wound healing activity for negative, positive, BP5, BU5, BU10, and BP10 groups were $72.51 \%, 69.36 \%, 70.14 \%, 81.70 \%, 86.54 \%$, and $80.21 \%$, respectively. The BU5 and BU10 showed significant activity $(p<0.05)$ compared with positive and negative controls.
\end{abstract}

Conclusion: BU10 provided the best wound healing activity and can be developed as a commercial product.

Key words: Ageratum conyzoides L., astaxanthin, Centella asiatica, gel preparation, wound healing

öz

Amaç: Çalışmanın amacı, Ageratum conyzoides L. yaprağı (beyaz ve mor), Centella asiatica ve astaksantin jel preparatının etanol ekstrelerinin kombinasyonunun yara iyileştirici aktivitesini belirlemekti.

Gereç ve Yöntemler: Jel hazırlamada, 3 farklı jelleştirme ajanı formülümüz vardı: Karbopol 934 (\%1), hidroksipropil metilselüloz (HPMC) (\%9) ve sodyum-karboksimetil selüloz (Na-CMC) (\%4). Daha sonra bu formülleri organoleptik özellikleri, pH'leri, yayılabilirlikleri ve viskoziteleri dahil olmak üzere farklı parametreler ile değerlendirdik. Yara iyileştirme aktivitesini belirlemek için oluşturulan altı grup: Negatif kontrol (plasebo), pozitif kontrol (bioplasenton), BP5 (beyaz çiçekli $A$. conyzoides L. yaprağının etanol ekstresi \%5, C. asiatica L. Urb yaprağı etanol ekstresi \%2,5 ve astaksantin $\% 0,05$ ), BU5 (mor çiçekli A. conyzoides L. yaprağının etanol ekstresi \%5, C. asiatica L. Urb yaprağı etanol ekstresi \%2,5 ve astaksantin \%0,05), BU10 
(mor çiçekli A. conyzoides L. yaprağının etanol ekstresi \%10, C. asiatica L. Urb yaprağı etanol ekstresi \%5 ve astaksantin \%0,1), BP10 (beyaz çiçekli A. conyzoides $L$. yaprağının etanol ekstresi \%10, C. asiatica L. Urb yaprağı etanol ekstresi \%5 ve astaksantin \%0,1) șeklindeydi. Tüm gruplar $1,5 \mathrm{~cm}$ uzunluğunda kesi ile tedavi edildi. Yara uzunluğunun ölçümü 14 gün boyunca günlük olarak gerçekleştirildi.

Bulgular: Karbopol 934 (\%1) jelleștirici madde formülü, değerlendirme testine göre HPMC ve Na-CMC'den daha iyiydi. Negatif, pozitif, BP5, BU 5, BU10 ve BP10 grupları için yara iyileștirme aktivitesi yüzdesi sırasıyla; $\% 72,51, \% 69,36, \% 70,14, \% 81,70, \% 86,54$ ve $\% 80,21$ olarak bulundu. BU5 ve BU10, pozitif ve negatif gruplara kıyasla anlamlı aktivite gösterdi ( $p<0,05)$.

Sonuç: BU10, en iyi yara iyileştirme aktivitesi gösteren formül olarak ticari olarak geliştirilme potansiyeli olan formülasyon olarak belirlendi.

Anahtar kelimeler: Ageratum conyzoides L, astaksantin, Centella asiatica, jel hazırlama, yara iyileșmesi

\section{INTRODUCTION}

A wound is defined as a physical, chemical, or thermal injury or insult that results in an opening or breaking in the integrity of the skin or disruption of anatomical and functional integrity of living tissues.' Global wound prevalence has reached $\sim 8.2$ million people, and medical care costs range from $\$ 28.1$ to $\$ 96.8$ billion. $^{2}$ Many wound healing products are available in the market. To date, there is no standard topical treatment for wound healing. Bioplacenton is a topical preparation that is available in the market. This product is commonly used for wound healing treatment by Indonesians. ${ }^{3}$ The ingredients of bioplacenton include neomycin sulfate $0.5 \%$ and placenta extract $10 \% .{ }^{4}$ Placenta extract accelerates the healing of the wound size, followed by reduction of transforming growth factor and elevation of vascular endothelial growth factor and CD $31^{+}$. $^{\circ}$

Ageratum conyzoides, Centella asiatica, and astaxanthin have been shown to have wound healing activity. ${ }^{6,7}$ Ethanolic extract of $A$. conyzoides exhibits a $40 \%$ increase in tissue tensile strength and a $33 \%$ decrease in re-epithelialization time, high collagen, and cellular infiltration. ${ }^{8}$ Different extractions of $C$. asiatica (hexane, ethyl acetate, methanol, and water extract) show tensile strength and develop epithelization and keratinization of the wounds. ${ }^{9}$ Asiaticoside and madecassoside from $C$. asiatica play an essential role in this wound healing activity. ${ }^{10}$ Astaxanthin is a powerful antioxidant, which is isolated from a lobster.11 Besides that, astaxanthin provides wound healing activity by reducing iNOS and increasing Col1A1 and bFGF.12 Col1A1 provides instructions for making collagen, which supports many tissues, including the skin. Meanwhile, bFGF regulates many biological functions, including tissue repair.13,14 However, the wound healing activity of these combinations is still unknown. Therefore, this study aimed to evaluate the wound healing activity of $A$. conyzoides, $C$. asiatica, and astaxanthin combination gel preparation.

\section{MATERIALS AND METHODS}

\section{Ethical clearance}

All the procedures were performed according to the Guide for the Care and Use of Laboratory Animals and approved by Bakti Tunas Husada Health Sciences College Ethical Committee (no: 03/kepk-bth/04/20).

\section{Plant materials and extract preparation}

$A$. conyzoides and $C$. asiatica leaves were collected from the Galunggung Mountain area, Tasikmalaya, West Java. The plants were authenticated by the School of Life Science and Technology, Institut Teknologi Bandung. Astaxanthin was obtained from Sigma Aldrich. The leaves were shade-dried and coarsely powdered by a grinder and stored in an airtight container at room temperature. The dried leaves of $A$. conyzoides L. (1000 g, purple flower type and $1000 \mathrm{~g}$ white flower type) and C. asiatica (2000 g) were used for maceration by ethanol $96 \%$ for $24 \mathrm{~h}$, and this process was repeated thrice. The extract was filtered and concentrated using a rotary evaporator at $60^{\circ} \mathrm{C}$. The percentage yield was calculated, and the extract was preserved in a refrigerator at $4^{\circ} \mathrm{C}$ until further use.

\section{Standardization of simplicia}

Simplicia was standardized using organoleptic, microscopic, and secondary metabolite analysis. The secondary metabolites, including alkaloid, flavonoid, polyphenol, quinone, tannin, monoterpenes-sesquiterpenes, triterpenoid, and steroid, were determined according to Fransworth's methods. ${ }^{15}$

\section{Preformulation of gel preparation}

The objective of the gel preformulation was to determine the best gel formula from three bases, including carbopol 934 $1 \%$, hydroxypropyl methylcellulose (HPMC) 9\%, and natirumcarboxymethylcellulose (Na-CMC) 4\%. The preformulation was checked for organoleptic, $\mathrm{pH}$, homogeneity, viscosity, and spreadability.

\section{Wound healing activity test}

The treatments were

(i) Negative control (placebo),

(ii) Positive control (Bioplacenton),

(iii) BP5 (A. conyzoides L. of white flower 5\%, C. asiatica L. Urb $2.5 \%$, astaxanthin 0.05\%),

(iv) BU5 (A. conyzoides L. of purple flower $5 \%, C$. asiatica L. Urb $2.5 \%$, astaxanthin $0.05 \%)$,

(v) BU10 (A. conyzoides L. of purple flower 10\%, C. asiatica L. Urb 5\%, and astaxanthin $0.1 \%$ ), and

(vi) BP10 (A. conyzoides L. of white flower $10 \%, C$. asiatica $L$. Urb $5 \%$, and astaxanthin $0.1 \%$ ). 
All treatments were applied to an incision wound of $1.5 \mathrm{~cm}$. The wound healing capacity was determined by daily measurement of the wound length using calipers for 14 days.

\section{Statistical analysis}

The obtained data were analyzed using analysis of variance, followed by posthoc test of least significant difference. The data were considered significant if the $p$ value was $<0.05$. All statistical analyses were performed using SPSS 16.00.

\section{RESULTS AND DISCUSSION}

\section{Standardization of simplicia}

The standard was evaluated based on organoleptic, microscopic, and non-specific parameters as well as phytochemical screening. The results of the organoleptic and microscopic parameters (Table 1), and non-specific parameters such as water content, ash content, dry shrinkage, and yields (Table 2) fulfilled the Indonesia Materia Medica Standard and Indonesia Herbal Pharmacopeia criteria.,16,17 Therefore, these simplicia were qualified for further wound healing test activity. Phytochemical screening study was positive for flavonoid, alkaloid, saponin, polyphenol, tannin, quinone, steroidtriterpenoid, and monoterpene-sesquiterpene, but negative for tannin (Table 3).

\section{Evaluation of the gel preparation}

In the organoleptic evaluation, carbopol 934 gel preparation gave the best texture and color compared with $\mathrm{Na}-\mathrm{CMC}$ and HPMC (Table 4, Figure 1). Thus, carbopol 934 bases in three concentrations $(0.5 \%, 1 \%$, and $1.5 \%)$ were used for further gel preparation formula evaluation (Table 5). The parameters, including stability, organoleptic, $\mathrm{pH}$, viscosity, and spreadability for three cycles at two temperatures, $2^{\circ} \mathrm{C}$ and $40^{\circ} \mathrm{C}$ (Table 6).

\section{Table 1. Organoleptic and microscopic data}

Simplicia

Centella asiatica L. Urb

Ageratum conyzoides L. leaf (purple flower type)
Organoleptic

Form: Powder

Color: Green

Odor: Aromatic typical

Taste: Bitter

Form: Powder

Color: Pale green

Odor: Aromatic typical

Taste: Bitter

Form: Powder

Color: Green

Odor: Aromatic typical

Taste: Bitter
Microscopic

Stomata, hair cover, oxalic acid, sklerenkim, epidermis, wooden vessel

Stomata, hair cover, secretion cells and essential oil, stomata

Stomata, hair cover, secretion cells, epidermis, wooden vessels

\section{Table 2. Non-specific parameters}

$\begin{array}{llll}\text { No. Parameters } & \text { Results (\%) Standard (\%) }\end{array}$

Water content

1 a. Ageratum conyzoides L. leaf (white flower type)

5.33

b. Ageratum conyzoides L. leaf (purple flower type)

c. Centella asiatica L. Urb

5.33

6.67

$<10$

Ash content

2 a. Ageratum conyzoides L. leaf (white flower type)

b. Ageratum conyzoides L. leaf (purple flower type)

11.84

10.57

10.60

$<13$

$<13$

c. Centella asiatica L. Urb

8.7

$<10$

a. Ageratum conyzoides L. leaf (white flower type)

9.91

9.68

$<10$

c. Centella asiatica L. Urb

20.16

13.87
11.74
a. Ageratum conyzoides L. leaf (white flower type)
b. Ageratum conyzoides L. leaf (purple flower type)
c. Centella asiatica L. Urb 
Table 3. Phytochemical screening

\begin{tabular}{|c|c|c|c|c|}
\hline \multirow{2}{*}{ Secondary metabolite } & \multicolumn{2}{|c|}{ Ageratum conyzoides L. leaf } & \multicolumn{2}{|c|}{ Centella asiatica L. Urb } \\
\hline & Simplicia & Extract & Simplicia & Extract \\
\hline Flavonoid & + & + & + & + \\
\hline Alkaloid & + & + & + & + \\
\hline Saponin & + & + & + & + \\
\hline Polyphenol & + & + & + & + \\
\hline Tannin & - & - & - & - \\
\hline Quinone & + & + & + & + \\
\hline Steroid/triterpenoid & + & + & + & + \\
\hline Monoterpene/sesquiterpene & + & + & + & + \\
\hline
\end{tabular}

+: Positive results, -: Negative results

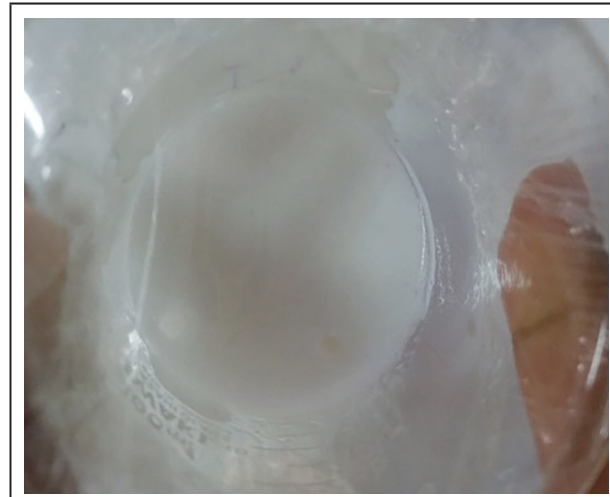

HPMC

Texture: Bubbly and liquid

Colour: Yellowish



Carbopol 934

Texture: Viscous

Colour: Clear

Figure 1. Organoleptic evaluation of three basis gel preformulation

HPMC: hydroxypropyl methylcellulose, Na-CMC: Natirum-carboxymethylcellulose

\section{Table 4. Preformulation of gel preparation}

\begin{tabular}{llll} 
Substances & F1 (\%) & F2 (\%) & F3 (\%) \\
\hline Carbopol 934 & - & - & 1 \\
\hline Hydroxypropyl methylcellulose & 9 & - & - \\
\hline Na-carboxymethylcellulose & - & 4 & - \\
\hline Propylenglycol & 15 & 2.5 & 2 \\
\hline Triethinolamine & - & - & qs \\
\hline Propyl paraben & 0.15 & 0.2 & - \\
\hline Methyl paraben & 0.18 & 0.18 & - \\
\hline Tween 80 & - & 2 & Ad $20 \mathrm{~g}$ \\
\hline Aquades & Ad $20 \mathrm{~g}$ & Ad $20 \mathrm{~g}$
\end{tabular}


Table 5. Formulation of gel preparation

\begin{tabular}{llll} 
Substances & F3a (\%) & F3b (\%) & F3c (\%) \\
\hline Carbopol 934 & 0.5 & 1 & 1.5 \\
\hline Propylenglycol & 2 & 2 & 2 \\
\hline Triethanolamine & qs & qs & qs \\
\hline DMDM hyndantoin & 0.5 & 0.5 & 0.5 \\
\hline Aquades & Ad 15 g & Ad 15 g & Ad 15 g \\
\hline
\end{tabular}

Table 6. Evaluation of gel preparation

\begin{tabular}{|c|c|c|c|c|}
\hline \multirow{2}{*}{ Parameter } & \multicolumn{3}{|c|}{ Hasil } & \multirow{2}{*}{ Standard } \\
\hline & F3a (\%) & F3b (\%) & F3c (\%) & \\
\hline Organoleptic & Yellowish & Clear & Clear & Clear \\
\hline Consistency & Viscous & Viscous & Viscous & Viscous \\
\hline $\mathrm{pH}$ & 7 & 6.25 & 6 & $4-6.5$ \\
\hline
\end{tabular}

The results of the evaluation showed that carbopol 1\% gave the best formulas and fulfilled the criteria. ${ }^{18-20}$ Hence, carbopol $1 \%$ (F3b) was combined with $A$. conyzoides $L$. leaf ethanolic extract (white and purple flower type), C. asiatica leaf ethanolic extract, and astaxanthin.

\section{The determination of wound healing activity}

Wound healing is comprised of three phases: Inflammation, proliferation, and remodeling. The first phase involves polymorphonuclear and macrophage inflammation, which last 3-5 days. The second phase is marked with a new tissue formation, fibroblast, endotel, and collagen formation. The third phase is the maturation phase that provides tensile strength, epithelium, and new tissue growth. ${ }^{21-23}$

The BU10 treatment showed the best wound healing activity compared with other groups ( $p<0.05)$ (negative and positive controls, BP5, and BP10), but not superior ( $p>0.05$ ) than BU5 (Figure 2, 3). The wound healing percentage of BU10 was $86.54 \%$, with complete remission time on the $8^{\text {th }}$ day (Figure 2). Meanwhile, the positive control (bioplacenton) showed no difference from the negative control ( $p>0.05$ ). Currently, we could not confirm this phenomenon.

The wound healing activity of BU10 may be due to the secondary metabolite composition in $A$. conyzoides $L$. leaf (purple flower type), C. asiatica, and the antioxidant activity of astaxanthin. ${ }^{13-14,24-29}$ The flavonoids in A. conyzoides L. leaf, such as kaempferol and quercetin, showed anti-inflammation, antioxidant, and immunomodulatory activity. ${ }^{24,25}$ Alkaloid and saponin composition of $A$. conyzoides $\mathrm{L}$. leaf also has a role in wound healing activity through fibroblast initiation, antiinflammation, cell repairing, and strength of the skin cells. ${ }^{26,27}$

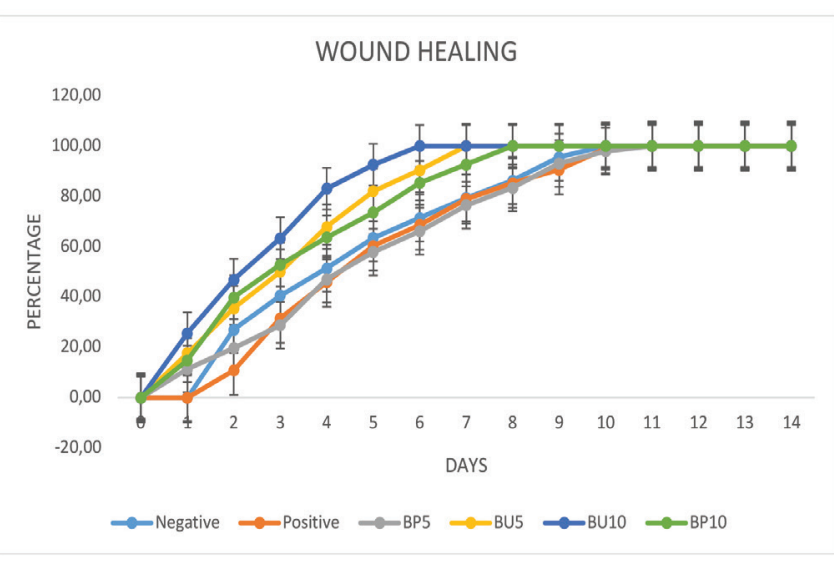

Figure 2. Wound healing activity test

Besides, C. asiatica secondary metabolites such as asiaticoside and madecassoside play an important role in wound healing activity although madecassoside is more effective than asiaticoside. ${ }^{10,28}$ Asiaticoside stimulates collagen, epidermis formation, antioxidant activity, and anti-inflammation activity, resulting in the inhibition of scar formation. ${ }^{28,29}$

\section{CONCLUSION}

The combination of $A$. conyzoides $L$. leaf ethanolic extract (purple flower type) 10\%, C. asiatica L. Urb leaf ethanolic extract $5 \%$, and astaxanthin $0.1 \%$ showed the best wound healing activity and can be developed as a commercial product. Future studies are required to determine the relationships between antioxidants and wound healing activities. 




Figure 3. Wound healing comparison between negative control vs. positive control vs. BU10

\section{ACKNOWLEDGMENTS}

The authors thank Yusuf Firmansyah for helping in animal care.

Conflict of interest: No conflict of interest was declared by the authors. The authors are solely responsible for the content and writing of this paper.

\section{REFERENCES}

1. Boakye YD, Agyare C, Ayande GP, Titiloye N, Asiamah EA, Danquah KO. Assessment of wound-healing properties of medicinal plants: the case of phyllanthus muellerianus. Front Pharmacol. 2018;9:945.

2. Sen CK. The Launch of advances in wound care: strengthening the interdisciplinary continuum of wound care. Adv Wound Care (New Rochelle). 2012;1:1-2. 
3. Wandasari C. Efektivitas gel putih telur pada penyembuhan luka bakar tikus putih (Rattus novergicus) melalui pengamatan jumlah fibroblas dan sel makrofag. Accessed date: 21.01.2021. Available from: http:// repository.wima.ac.id/8052/2/BAB1\%202443012253.pdf

4. MIMS. Bioplacenton. Accessed date: 21.01.2021. Available from: https:// www.mims.com/indonesia/drug/info/bioplacenton?lang=id

5. Hong JW, Lee WJ, Hahn SB, Kim BJ, Lew DH. The effect of human placenta extract in a wound healing model. Ann Plast Surg. 2010;65:96100

6. Shedoeva A, Leafley D,Upton Z, Fan C. Wound healing and the use of medicinal plants. Evidence Based Complementary and Altern Med. 2019;2684108:1-30.

7. Sukmawan YP, Aryani R. Uji aktivitas penyembuhan luka formula gel ekstrak etanol daun babadotan (Ageratum conyzoides $\mathrm{L}$ ) terhadap tikus jantan wistar. Jurnal STIKes BTH. 2016;16:88-93.

8. Arulprakash K, Murugan R, Ponrasu T, lyappan K, Gayathri VS, Suguna L. Efficacy of Ageratum conyzoides on tissue repair and collagen formation in rats. Clin Exp Dermatol. 2012;37:418-424.

9. Somboonwong J, Kankaisre M, Tantisira B, Tantisira MH. Wound healing activities of different extracts of Centella asiatica in incision and burn wound models: an experimental animal study. BMC Complement Altern Med. 2012;12:103

10. Wu F, Bian D,Xia Y,Gong Z, Tan Q, Chen J, Dai Y. Identification of major active ingredients responsible for burn wound healing of centella asiatica herbs. Evid Based Complement Alternat Med. 2012;848093:1-13.

11. Davinelli S, Nielsen ME, Scapagnini G. Astaxanthin in skin health, repair, and disease: a comprehensive review. Nutrients. 2018;10:522.

12. Meephansan J, Rungjang A, Yingmema W, Deenonpoe R, Ponnikorn S. Effect of astaxanthin on cutaneous wound healing. Clin Cosmet Investig Dermatol. 2017;10:259-265.

13. US. National Library of Medicine. Genetics Home Reference: COL1A1 Gene. Accessed date: July 7, 2020. Available from: https://ghr.nlm.nih. gov/gene/COL1A1\#: :text=Normal\%20Function,the\%20eye\%20(the\%20 sclera).

14. Yun YR, Won JE, Jeon E. Fibroblast growth factors: biology, function, and application for tissue regeneration. J Tissue Eng. 2010;2010:218142.

15. Fransworth NR. Biological and phytochemical screening of plants. J Pharm Sci. 1996;55:225-276.
16. Departemen Kesehatan RI. Materia Medika Indonesia Jilid VI. Jakarta: Departemen Kesehatan RI; 1995.

17. Departemen Kesehatan RI. Farmakope Herbal Indonesia, Edisi 1. Jakarta : Departemen Kesehatan RI. 2009. Available from: https:// farmalkes.kemkes.go.id/2020/08/farmakope-herbal-indonesia-edisi-iitahun-2017-3/

18. Garg AD, Garg AS, Sigla AK. Spreading of semisolid formulation: an update. Pharm Technol. 2002;26:84-102.

19. Voigt, R. Buku Pengantar Teknologi Farmasi, diterjemahkan oleh Soedani, N. Edisi V. Yogyakarta: Universitas Gadjah Mada Press; 1994

20. Voigt, R. Buku Pengantar Teknologi Farmasi. Yogyakarta: Universitas Gadjah Mada Press; 1995.

21. Carville K. Wound care: Manual ( $5^{\text {th }}$ ed). Osborne Park: Silver Chain Foundation; 2007

22. Landen NX, Li D, Stahle M. Transition from Inflammation to proliferation: a critical step during wound healing. Cell Mol Life Sci. 2016;73:38613885 .

23. Velnar T, Bailey $T$, Smrkolj V. The wound healing process: an overview of the cellular and molecular mechanism. J Int Med Res. 2009;37:15281542.

24. Suhendy H, Sukmawan YP. Aktivitas immunomodulator ekstrak etanol daun babadotan [Ageratum conyzoides ( L .)]. J Pharmacopol. 2019;2:9-14.

25. Sukmawan YP, dan Aryanti R. Uji aktivitas penyembuhan luka formula gel ekstrak etanol daun babadotan (Ageratum conyzoides $L$ ) terhadap tikus. Jurnal Kesehatan Bakti Tunas Husada. 2016;16:88-93.

26. Safani EE, Kunharjito WAC, Lestari A, Purnama ER. Potensi ekstrak daun bandotan (Ageratum conyzoides L.) sebagai spray untuk pemulihan luka mencit diabetik yang terinfeksi Staphylococcus aureus. J Tropic Biol. 2019;3:69.

27. Sartika DD. Efek lumatan daun dewa (gynura segetum) dalam memperpendek waktu penyembuhan luka bersih pada tikus putih. Jurnal Keperawatan Soedirman. 2010;5:127-135.

28. Kurnianto S, Kusnanto K, Padoli P. Penyembuhan luka bakar pada tikus putih dengan menggunakan ekstrak daun pegagan (Centella asiatica) 25\% dan ekstrak daun petai cina (leucaena leucocephala) 30\%. Jurnal IImiah Kesehatan. 2017;10:250-255.

29. Mizuta M, Hirano S, Hiwatashi N, Tateya I, Kanemaru S, Nakamura T, Ito J. Effect of astaxanthin on vocal fold wound healing. Laryngoscope. 2014;124:E1-E7. 